\title{
Assessment of safety and quality of fermented milk of camels, cows, and goats sold and consumed in five localities of Burkina Faso
}

\author{
Hama Cissé, Jean Ulrich Muandze-Nzambe, Namwin Siourimè Somda, Adama Sawadogo, Soungalo Moustapha Drabo, \\ François Tapsoba, Cheikna Zongo, Yves Traoré and Aly Savadogo
}

Laboratory of Applied Biochemistry and Immunology, University Ouaga 1 Pr Joseph KI-ZERBO, 03 BP 7021 Ouagadougou 03, Burkina Faso.

Corresponding author: Aly Savadogo, e-mail: alysavadogo@gmail.com

Co-authors: HC: cissehama70@gmail.com, JUM: milulrich@yahoo.fr, NSS: landsom60@yahoo.fr, AS: damouss75@yahoo.fr, SMD: mousyoung@gmail.com, FT: tapsobaf@gmail.com, CZ: zcheik@yahoo.fr, YT: ytraore@yahoo.com

Received: 23-11-2018, Accepted: 17-01-2019, Published online: 22-02-2019

doi: 10.14202/vetworld.2019.295-304 How to cite this article: Cissé H, Muandze-Nzambe JU, Somda NS, Sawadogo A, Drabo SM, Tapsoba F, Zongo C, Traoré Y, Savadogo A (2019) Assessment of safety and quality of fermented milk of camels, cows, and goats sold and consumed in five localities of Burkina Faso, Veterinary World, 12(2): 295-304.

\begin{abstract}
Background and Aim: Fermented milk is food produced and consumed all over the world and plays an important role in human nutrition. This work aimed to evaluate the microbiological and physicochemical quality and mineral composition of fermented milk consumed in Burkina Faso.

Materials and Methods: A total of 114 samples of fermented milk from camels, goats, and cows were purchased in the market in five localities in Burkina Faso; Bobo Dioulasso, Djibo, Dori, Gorom-Gorom, and Sebba. Microbiological and physical parameters were monitored using standards methods.

Results: Microbiological analysis of fermented milks showed high average values of $7.60 \pm 1.50 \times 10^{9}$ colony-forming unit per milliliter (CFU/ml), $5.72 \pm 3.60 \times 10^{7} \mathrm{CFU} / \mathrm{ml}, 5.53 \pm 2.00 \times 10^{5} \mathrm{CFU} / \mathrm{ml}, 1.97 \pm 0.18 \times 10^{3} \mathrm{CFU} / \mathrm{ml}, 1.98 \pm 0.25 \times 10^{3} \mathrm{CFU} /$ $\mathrm{ml}$, and $0.10 \pm 0.09 \times 10^{3} \mathrm{CFU} / \mathrm{ml}$ for total microbial flora, lactic acid bacteria, yeasts and molds, Staphylococcus aureus, total coliforms, and thermotolerant coliforms, respectively. None of the samples were contaminated by Salmonella or Shigella. The average values of $\mathrm{pH}$, acidity, dry matter, ash, fats, proteins, and total carbohydrates content of samples were ranged, respectively: $3.830-4.137,1.888-2.822 \%, 8.271-13.004 \%, 0.199-0.476 \%, 1.210-3.863 \%, 2.125-3.764 \%$, and 3.080 $5.428 \%(\mathrm{w} / \mathrm{w})$. Na/K and $\mathrm{Ca} / \mathrm{Mg}$ ratio ranged from 0.104 to 0.909 and from 3.392 to 16.996 , respectively. Total microbial flora, yeasts and molds, total coliforms, fats, calcium, potassium, iron, and zinc were significantly different.
\end{abstract}

Conclusion: This research contributed in the evaluation of the hygienic and nutritional qualities of local fermented milk. Results obtained in this study confirm the need to set up the training program on the sanitary condition to traditional maker's to ensure the good fermented milk with high organoleptic and nutritional qualities.

Keywords: Burkina Faso, camel, cow, fermented milk, goat, sanitary quality.

\section{Introduction}

Milk is the natural product of the secretion of the mammary gland of a lactating female. It is an essential component of the diet of pastoral or agropastoral populations and also an important source of income in Sahelian countries. Milk plays an important role in bone growth, maintaining body integrity and health through its composition of minerals, fats, proteins, carbohydrates and vitamins [1]. Milk microbiota contains many bacteria, some are useful and necessary for her transformation to other products as lactic acid bacteria or molds used for the maturing of cheese and yeasts transforming sugars to alcohol [2-4].

According to composition, raw milk is an ideal medium for the growth of many microorganisms,

Copyright: Cissé, et al. Open Access. This article is distributed under the terms of the Creative Commons Attribution 4.0 International License (http://creativecommons.org/licenses/by/4.0/), which permits unrestricted use, distribution, and reproduction in any medium, provided you give appropriate credit to the original author(s) and the source, provide a link to the Creative Commons license, and indicate if changes were made. The Creative Commons Public Domain Dedication waiver (http://creativecommons.org/ publicdomain/zero/1.0/) applies to the data made available in this article, unless otherwise stated. unlike fermented milk, where there is a predominance of lactic acid bacteria with some contaminants as Bacillus, Staphylococcus, and Escherichia coli $[5,6]$. Cow milk is the most milk consumed in the world followed by that of goat, camel, buffalo, mare, and donkey. Taste of camel's milk varies according to the pasture, is appreciated for its anti-infectious, anticancer, antidiabetic, and reconstructive properties in convalescent patients [7,8]. In other countries as Central Asia, mare milk is used to replaces maternal milk for infants. In Africa and particularly in Burkina Faso, for ethnic and cultural reasons only, the milk of sheep, camel, goat, and cows is consumed. The use of unconventional milk (donkey and mare) is culturally important. Consumers of these products attribute to their medicinal and mystical properties during occult practices. Conventionally, the origin of the milk fermentation is correlated to the appearance of nomadic peoples (Fulani). Fermented milk is a traditional remedy used by the old medical sciences of agropastoral communities. In Burkina Faso, there is a greater diversity of dairy products in diets of the populations which include raw milk, fermented milk, pasteurized 
milk, yogurt, cheese, cream, butter, gappal, dèguè, and soap Fulani [9]. In the past, fermented dairy products as yogurt, fermented milks, and cheese have been recognized as foods with undeniable nutritional qualities [10-12]. Recently, a diversity of yogurt (yogurt with Moringa, pineapple, sweetened, and unsweetened) is sold by local producers in Burkina Faso. These foods are perishable and often contaminated by microorganisms, antibiotics, pesticides (insecticides), detergents, and disinfectants [13]. The hygienic quality of milk and dairy products is considered, as one of the major factors limiting their consumption. Other factors influencing the quality of these products include lack of knowledge in good hygiene practices, preservation conditions, and certain chemical additives used.

This work aimed to evaluate the microbiological, physicochemical, and nutritional qualities of fermented milk produced and consumed in Burkina Faso.

\section{Materials and Methods}

\section{Ethical approval}

Ethical approval does not apply to this type of study. Samples of fermented milk were purchased from the vendors and analyzed in our laboratory.

\section{Sampling}

A total of 114 fermented milk samples (camel, cow, and goat) produced by the traditional method, purchased from the markets and streets of five cities in Burkina Faso, were collected aseptically from local producers and transported to the laboratory at $4-5^{\circ} \mathrm{C}$ using icebox for the different analysis. Figure- 1 and Table-1 presented, respectively, sampling sites and samples coding.

\section{Microbiological analysis}

Microbiological analyses of fermented milk were performed according to standard methods described in the manual of microbiological analysis. The bacterial populations in fermented milk were enumerated after prepared stock solution and decimal dilutions according to standard microbial methods. $10 \mathrm{ml}$ of the sample were added to $90 \mathrm{ml}$ of sterile buffered peptone water, and serial dilutions were monitored with this suspension. All tests were done in duplicate. The results were expressed as colony-forming unit per milliliter (CFU/ml). Total microbial flora was enumerated on plate count agar after incubation at $30^{\circ} \mathrm{C}$ during 24-48 h. Lactic acid bacteria were enumerated on plates of Man, Rogosa, and Sharpe agar, after incubation at $37^{\circ} \mathrm{C}$ for $24-48 \mathrm{~h}$ anaerobically (anaerobic jars with Anaerocult A). Yeasts and molds were enumerated on Sabouraud CAF agar with chloramphenicol, after incubation at $25^{\circ} \mathrm{C}$ for 3-5 days. Total coliforms and thermotolerant coliforms were counted on eosin methylene blue agar at $37^{\circ} \mathrm{C}$ and $44^{\circ} \mathrm{C}$ for $24-48 \mathrm{~h}$. Staphylococcus aureus were counted on Baird-Parker agar supplemented with tellurium egg yolk and incubated at $37^{\circ} \mathrm{C}$ for $24-48 \mathrm{~h}$, the black brilliant or dark gray colonies surrounded a clear halo were selected and tested for the confirmation (Gram, catalase, and coagulase tests). The research of Salmonella or Shigella spp. was carried by pre-enrichment with buffered peptone water followed by enrichment in RappaportVassiliadis broth and isolation on Salmonella-Shigella agar for $24 \mathrm{~h}$ at $37^{\circ} \mathrm{C}$ after each part.

\section{Physicochemical analysis}

The samples were mixed and analyzed in duplicate for the determination of different parameters physicochemical. The $\mathrm{pH}$ was determined using a digital $\mathrm{pH}$ meter (WATERPROOF-PC5). Titratable acidity, dry matter, ash, fats, and protein contents were determined according to AOAC [14]. Total carbohydrates were calculated according to this formula: Total carbohydrate $=$ Total solids $-($ Fat + Protein + Ash) [15].

\section{Minerals determination}

For the determination of mineral elements, the ash was dissolved in $100 \mathrm{ml}$ of concentrated $\mathrm{HNO}_{3}$

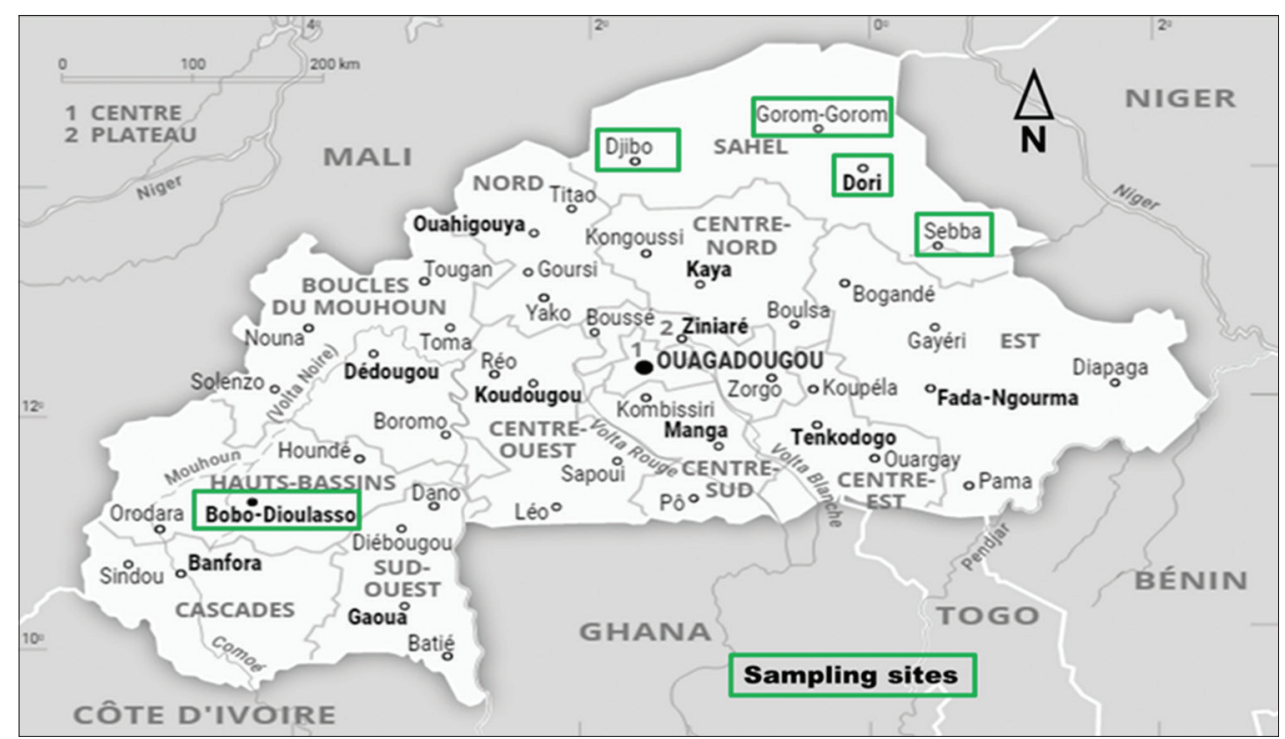

Figure-1: Localities of collected samples (Source: https://www.universalis.fr/atlas/afrique/burkina-faso/\#AT003203). 
Table-1: Coding of samples.

\begin{tabular}{lccccc}
\hline Fermented milk & \multicolumn{3}{c}{ Localities and coding } \\
\cline { 2 - 6 } & Bobo Dioulasso & Djibo & Dori & Gorom-Gorom & Sebba \\
\hline Camel & - & CaJ & CaD & CaG & CaS \\
Cow & CoB & CoJ & CoD & CoG & CoS \\
Goat & - & GoJ & GoD & GoG & GoS \\
\hline
\end{tabular}

Table-2: Characteristics of the calibration curves of minerals.

\begin{tabular}{|c|c|c|c|c|c|c|}
\hline Mineral & $\begin{array}{c}\text { Standard } \\
\text { concentration }(\mathrm{mg} / \mathrm{L})\end{array}$ & $\lambda(\mathrm{nm})$ & $\begin{array}{l}\text { Standard } \\
\text { solution }\end{array}$ & $\begin{array}{l}\text { Standard } \\
\text { gas }\end{array}$ & Dependence $^{a}$ & $\begin{array}{l}\text { Correlation } \\
\text { coefficient }\end{array}$ \\
\hline $\mathrm{Ca}^{2+}$ & 0.0551 & 422.70 & $\mathrm{HNO}_{3}$ & Air/acetylene & $y=0.07993 \times c$ & 0.9985 \\
\hline $\mathrm{Fe}^{2+}$ & 0.1904 & 248.20 & $\mathrm{HNO}_{3}^{3}$ & Air/acetylene & $y=0.02311 \times c$ & 0.9996 \\
\hline $\mathrm{K}^{+}$ & 0.1497 & 766.50 & $\mathrm{HNO}_{3}$ & Air/acetylene & $y=0.039 \times c-0.0015$ & 0.9776 \\
\hline $\mathrm{Mg}^{2+}$ & 0.0098 & 285.20 & $\mathrm{HNO}_{3}$ & Air/acetylene & $y=0.45101 \times c$ & 0.9895 \\
\hline $\mathrm{Na}^{2+}$ & 0.0477 & 589.00 & $\mathrm{HNO}_{3}^{3}$ & Air/acetylene & $y=0.09215 \times c$ & 0.9899 \\
\hline $\mathrm{Zn}^{2+}$ & 0.0499 & 213.90 & $\mathrm{HNO}_{3}$ & Air/acetylene & $y=0.08810 \times c$ & 0.9889 \\
\hline
\end{tabular}

${ }^{\mathrm{a}} \mathrm{y}=$ Flame photometer reading, $\mathrm{c}=$ Concentration in $\mathrm{mg} / \mathrm{L}, \lambda=$ Wavelength, $\mathrm{Ca}^{2+}=$ Calcium, $\mathrm{K}^{+}=$Potassium, $\mathrm{Na}^{2+}=\mathrm{Sodium}$ $\mathrm{Mg}^{2+}=$ Magnesium, $\mathrm{Fe}^{2+}=$ Iron, $\mathrm{Zn}^{2+}=$ Zinc

Table-3: Microbiological parameters of different fermented milk samples.

\begin{tabular}{|c|c|c|c|c|c|c|c|}
\hline Samples & TMF $\times 10^{9}$ & $\mathrm{LAB} \times 10^{7}$ & $Y \& M \times 10^{5}$ & S. aureus $\times 10^{3}$ & $\mathrm{TC} \times 10^{3}$ & TTC $\times 10^{3}$ & ss \\
\hline $\operatorname{CaD}(\mathrm{n}=6)$ & $0.39 \pm 0.27^{c}$ & $0.43 \pm 0.34^{c}$ & $5.44 \pm 3.00^{a}$ & $0.18 \pm 0.06^{c}$ & $0.13 \pm 0.06^{\mathrm{de}}$ & $0.06 \pm 0.03^{a b}$ & $\mathrm{Nd}$ \\
\hline$C a G(n=10)$ & $4.08 \pm 1.80^{\mathrm{b}}$ & $2.53 \pm 2.37^{\mathrm{abc}}$ & $0.34 \pm 2.70^{c}$ & $0.21 \pm 0.05^{c}$ & $0.06 \pm 0.04^{\mathrm{e}}$ & $0.02 \pm 0.01^{\mathrm{b}}$ & $\mathrm{Nd}$ \\
\hline $\operatorname{CaS}(n=4)$ & $0.41 \pm 0.10^{c}$ & $3.10 \pm 2.90^{\mathrm{abc}}$ & $5.53 \pm 2.00^{\mathrm{a}}$ & $1.97 \pm 1.18^{\mathrm{a}}$ & $0.17 \pm 0.07^{\mathrm{de}}$ & $0.08 \pm 0.04 b^{a b}$ & $\mathrm{Nd}$ \\
\hline CaJ $(n=4)$ & $4.60 \pm 1.39^{b}$ & $4.08 \pm 3.60^{\mathrm{ab}}$ & $0.47 \pm 0.28^{c}$ & $1.23 \pm 0.39 \mathrm{abc}$ & $0.08 \pm 0.06^{e}$ & $0.02 \pm 0.00 b^{a b}$ & $\mathrm{Nd}$ \\
\hline $\operatorname{CoB}(n=10)$ & $3.76 \pm 2.30^{\mathrm{b}}$ & $2.37 \pm 1.30^{\mathrm{abc}}$ & $0.63 \pm 0.30^{\mathrm{bc}}$ & $0.62 \pm 0.53^{b c}$ & $0.17 \pm 0.12^{\mathrm{de}}$ & $0.03 \pm 0.04^{\mathrm{ab}}$ & $\mathrm{Nd}$ \\
\hline $\operatorname{CoD}(\mathrm{n}=10)$ & $0.50 \pm 0.32^{c}$ & $0.52 \pm 0.27^{b c}$ & $4.71 \pm 2.60^{a}$ & $0.54 \pm 0.52^{b c}$ & $0.21 \pm 0.17^{\mathrm{de}}$ & $0.04 \pm 0.01^{\mathrm{ab}}$ & $\mathrm{Nd}$ \\
\hline $\operatorname{Cog}(n=10)$ & $0.55 \pm 0.26^{\mathrm{ab}}$ & $4.37 \pm 3.00^{\mathrm{ab}}$ & $4.35 \pm 3.50^{a}$ & $0.86 \pm 0.64^{a b c}$ & $0.26 \pm 0.12^{\text {cde }}$ & $0.04 \pm 0.07^{a b}$ & $\mathrm{Nd}$ \\
\hline $\operatorname{Cos}(n=10)$ & $3.38 \pm 0.89^{b}$ & $5.20 \pm 2.70^{a}$ & $3.82 \pm 1.00^{\mathrm{abc}}$ & $1.03 \pm 0.30^{\mathrm{abc}}$ & $1.31 \pm 0.28^{b}$ & $0.08 \pm 0.07^{a b}$ & $\mathrm{Nd}$ \\
\hline $\operatorname{CoJ}(n=10)$ & $7.60 \pm 1.50^{a}$ & $3.33 \pm 1.38^{\mathrm{abc}}$ & $0.41 \pm 0.26^{c}$ & $0.81 \pm 0.64^{b c}$ & $0.16 \pm 0.12^{\mathrm{de}}$ & $0.04 \pm 0.03^{\mathrm{ab}}$ & $\mathrm{Nd}$ \\
\hline GoD $(n=10)$ & $4.99 \pm 2.70^{b}$ & $5.57 \pm 3.20^{\mathrm{a}}$ & $4.18 \pm 3.00^{\mathrm{a}}$ & $0.87 \pm 0.84^{\mathrm{abc}}$ & $0.16 \pm 0.09^{\mathrm{de}}$ & $0.03 \pm 0.03^{\mathrm{ab}}$ & $\mathrm{Nd}$ \\
\hline GoG $(n=10)$ & $0.67 \pm 0.22^{c}$ & $3.09 \pm 1.10^{\mathrm{abc}}$ & $4.81 \pm 2.96^{\mathrm{a}}$ & $1.54 \pm 0.13^{\mathrm{ab}}$ & $1.98 \pm 0.38^{\mathrm{a}}$ & $0.06 \pm 0.04^{\mathrm{ab}}$ & $\mathrm{Nd}$ \\
\hline $\operatorname{GoS}(n=10)$ & $4.05 \pm 2.80^{b}$ & $5.72 \pm 3.60^{\mathrm{a}}$ & $0.33 \pm 0.09^{c}$ & $0.82 \pm 0.70^{\mathrm{bc}}$ & $0.57 \pm 0.25^{c}$ & $0.07 \pm 0.06^{\mathrm{ab}}$ & $\mathrm{Nd}$ \\
\hline GoJ $(n=10)$ & $0.33 \pm 0.13^{c}$ & $0.53 \pm 0.28^{\mathrm{bc}}$ & $3.27 \pm 2.95^{\mathrm{abc}}$ & $1.13 \pm 1.02^{\mathrm{abc}}$ & $0.43 \pm 0.50^{\mathrm{cd}}$ & $0.10 \pm 0.12^{\mathrm{a}}$ & $\mathrm{Nd}$ \\
\hline P-value & $0.0000 * * * *$ & 0.052 (NS) & $0.016 *$ & 0.084 (NS) & $0.0000 * * * *$ & 0.405 (NS) & --- \\
\hline
\end{tabular}

Values bearing different letters in a column are significantly different $(p<0.05)$, NS=Not significant, TMF=Total microbial flora, LAB =Lactic acid bacteria, Y\&M: Yeasts and molds, S. aureus=Staphylococcus aureus, TC=Total coliforms, $\mathrm{TTC}=$ Thermotolerant coliforms, $\mathrm{SS}=$ Salmonella or Shigella, $\mathrm{Nd}=$ Not detected

at $0.5 \mathrm{M}$. The composition in $\mathrm{Ca}^{2+}$, potassium $\left(\mathrm{K}^{+}\right)$, sodium $\left(\mathrm{Na}^{2+}\right)$, magnesium $\left(\mathrm{Mg}^{2+}\right)$, iron $\left(\mathrm{Fe}^{2+}\right)$, and zinc $\left(\mathrm{Zn}^{2+}\right)$ was determined by Fast Sequential Atomic Absorption Spectrometer AA240FS according to AOAC [14]. Table-2 presented the characteristics of analytical curves.

\section{Statistical analysis}

The data were analyzed using analysis of variance by program XLSTAT 2017 and modeled using R software, version 3.4.2 (R Foundation for Statistical Computing, Austria).

The results were expressed as average \pm standard deviation. The difference between the means was calculated using least significant difference Fisher's test, and $\mathrm{p}<0.05$ was considered statistically significant.

\section{Results}

The average densities of various microorganisms determined are summarized in Table-3. This result showed a significant load of total microbial flora with high variations of $0.33-7.60 \times 10^{9} \mathrm{CFU} / \mathrm{ml}$. Lactic acid bacteria were found at $0.43-5.72 \times 10^{7} \mathrm{CFU} / \mathrm{ml}$. Yeasts and molds count ranged from 0.33 to $5.53 \times 10^{5}$ $\mathrm{CFU} / \mathrm{ml}$, showing an increasing trend during fermentation. According to the results of this study, total coliform densities were 0.06 at $1.98 \times 10^{3} \mathrm{CFU} / \mathrm{ml}$, and thermotolerant coliform densities ranged from 0.02 to $0.10 \times 10^{3} \mathrm{CFU} / \mathrm{ml}$. S. aureus densities were in the range of $0.18-1.97 \times 10^{3} \mathrm{CFU} / \mathrm{ml}$ in traditional fermented milk and yogurt sold at acidic $\mathrm{pH}(>3)$. Table- 3 reveals that Salmonella and Shigella were absent in all analyzed samples. After analyzing the distribution of centers gravity classes on principal factorial plane (Figure-2), we can be noted some closeness between the types of milk and variables. The variables and samples are visualized in the factorial plane formed on dimensions 1 and 2 ( $71 \%$ of variance explained, Figure-2). According to dimension 1, CoS and $G o S$ were highly contaminated with total coliforms, $S$. aureus, and lactic acid bacteria, unlike $C a D$ and $C o D$ which were less 


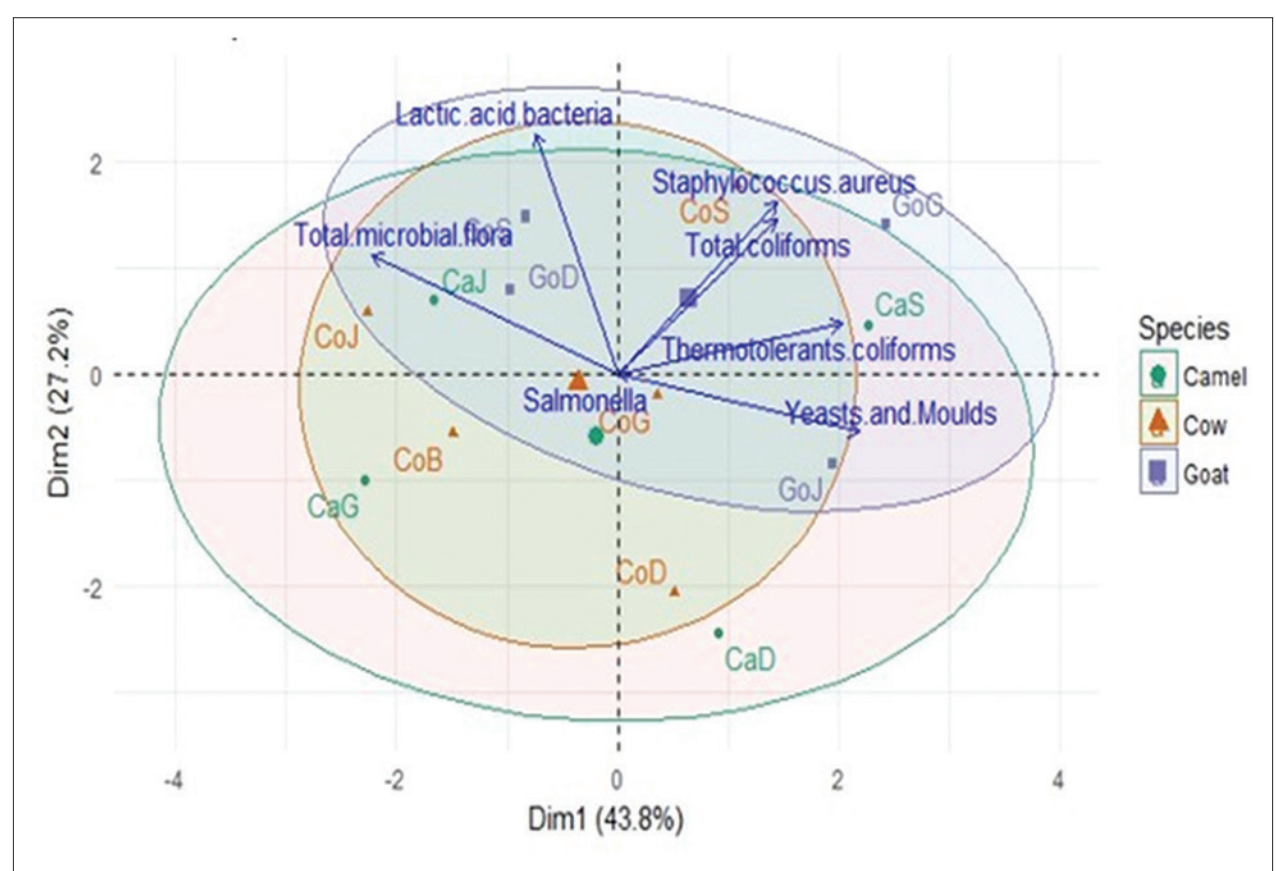

Figure-2: Principal component analysis distribution of fermented milk samples and ellipse of inertia different species on the factorial plane according to microbiological parameter.

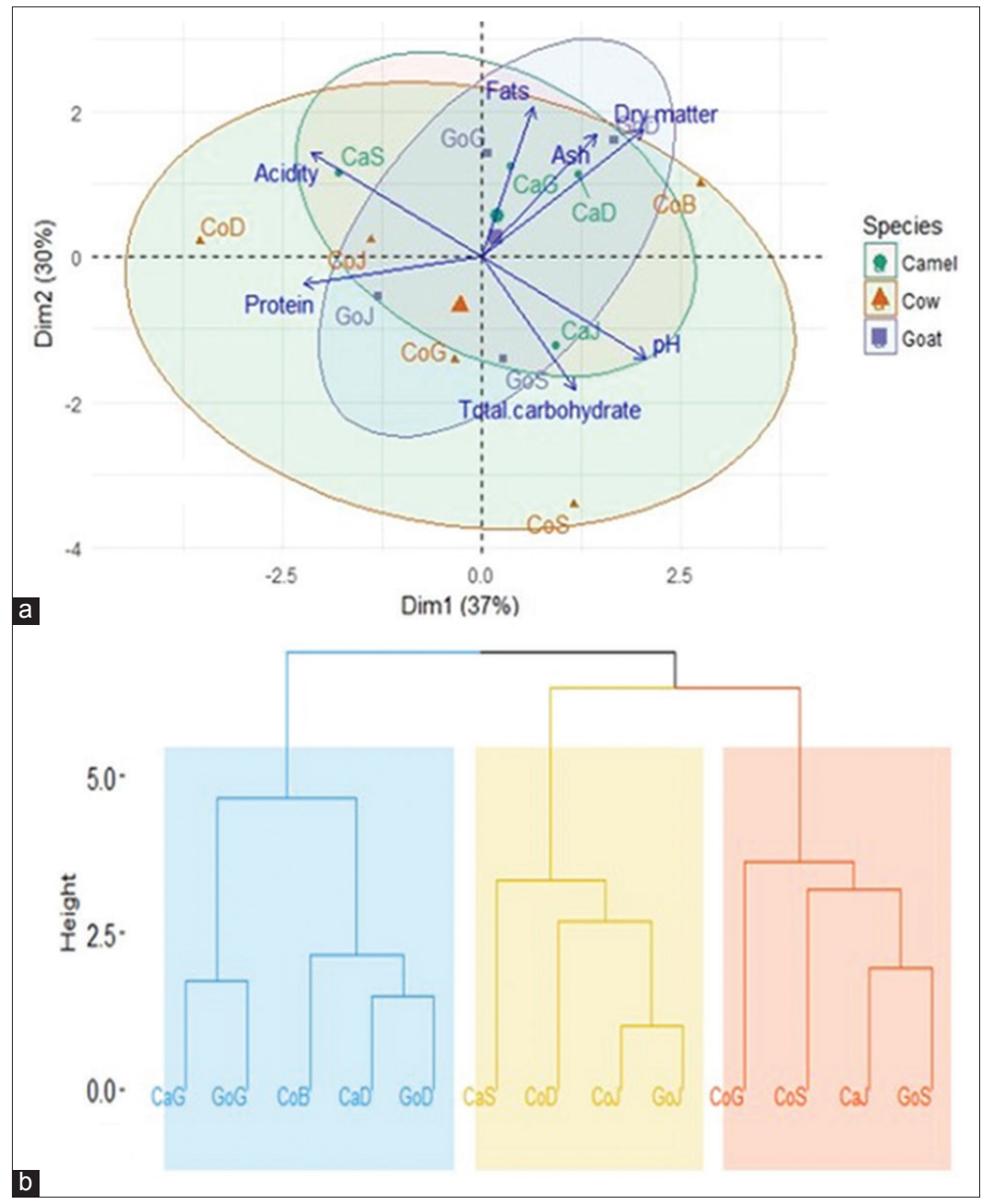

Figure-3: Principal component analysis distribution of fermented milk samples and ellipse of inertia different species on the factorial plane according to physicochemical parameters (a), ascending hierarchical clusters according to physicochemical parameters of fermented milk from different species (b). 


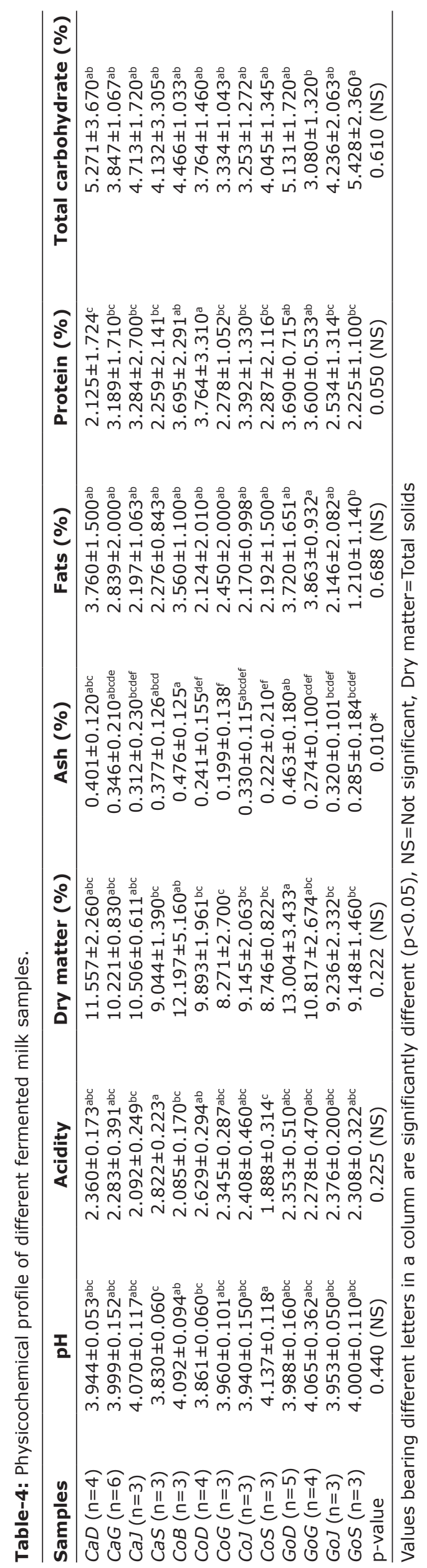

contaminated. The dimension 2 reveals that $\mathrm{CaJ}, \mathrm{CaS}$, $C o J, G o D$, GoJ, and $G o G$ were highly contaminated with yeasts and molds and thermotolerant coliforms, but they were weakly contaminated by total microbial flora, while $C a G, C o B$, and $C o G$ were contaminated with total microbial flora but weakly contaminated by yeasts and molds and thermotolerant coliforms.

Table-4 presents the average values of physicochemical parameters of fermented milk collected from different localities. A significant decrease in $\mathrm{pH}$ from 3.830 to 4.137 and a significant increase in acidity from 1.888 to 2.822 were found for fermented milk samples. The dry matters and ashes ranged, respectively, from 8.271 to 13.004 and from 1.994 to 4.761 . Dry matter contents varied from $8.271 \%$ to $13.004 \%$ and ash values were significantly different between the samples collected from $0.199 \%$ to $0.476 \%$. The biochemical composition of fermented milk samples varied as follows: Fats (1.210-3.863\%), proteins (2.125-3.764\%), and total carbohydrates (3.080$5.428 \%$ ). Analyzing the distribution of center gravity classes on principal factorial plane (Figure-3a), it reveals a homogeneity of the groups of milk from different animal species according to the physicochemical parameters. Dimension 1 indicated that $\mathrm{CaG}$, $C a D, G o G$, and $G o D$ contain high rate of fats, ash, dry matter, and less rate of total carbohydrate, contrary to $\mathrm{CaJ}, \mathrm{GoS}, \mathrm{CoS}$, and $\mathrm{CoG}$ who are rich total carbohydrate and poor in fats, ash, and dry matter. Dimension 2 reveals a high acidity, low $\mathrm{pH}$, and low rate of protein samples content for the following $C a S, C o D, C o J$, and $C o B$ while $G o J$ is rich in protein and has high $\mathrm{pH}$. The Ascending Hierarchical Clustering (AHC) led to a dendrogram which regrouped three major clusters according to their physicochemical parameters from different species (Figure-3b). The first cluster included the following samples $C a G, G o G, C o B, C a D$, and $G o D$. The second cluster included the fermented milk samples $C a S, C o D, C o J$, and GoJ, and the third cluster contained the samples $C o G, C o S, C a J$, and $G o S$. Table- 5 shows that the mean values of major elements $\left(\mathrm{Ca}^{2+}, \mathrm{Na}^{2+}\right.$, and $\left.\mathrm{K}^{+}\right)$in fermented milk were 855.430 $(\mathrm{CaJ}), 424.296(\mathrm{Ca} G)$, and $1427.383(\mathrm{CoG})$ while the mean values of some minor elements $\left(\mathrm{Fe}^{2+}, \mathrm{Zn}^{2+}\right.$, and $\left.\mathrm{Mg}^{2+}\right)$ were $4.421(\mathrm{CoJ}), 7.450(\mathrm{CoD})$, and 104.941 $(C o D)$, respectively. The $\mathrm{Na}^{2+} / \mathrm{K}^{+}$and $\mathrm{Na}^{2+} / \mathrm{K}^{+}$ratios obtained for the different fermented milk were ranged 0.104-0.909 and 3.392-6.464, respectively. Analyzing the distribution of centers gravity classes on the main factorial plane (Figure-4a), we can observe that camel milk with cow milk was close but goat milk deviated by its composition. The result of principal component analysis performed on the minerals concentration of different fermented milk samples showed that the first two axes explained $69.0 \%$ of the variation observed (Figure-4a). Therefore, only the first two axes were used to describe the relationship between mineral concentration and species samples. Dimension 1 shows that $C o S, C o B, C a G$, and $C o G$ were poor in $\mathrm{K}^{+}$, but 


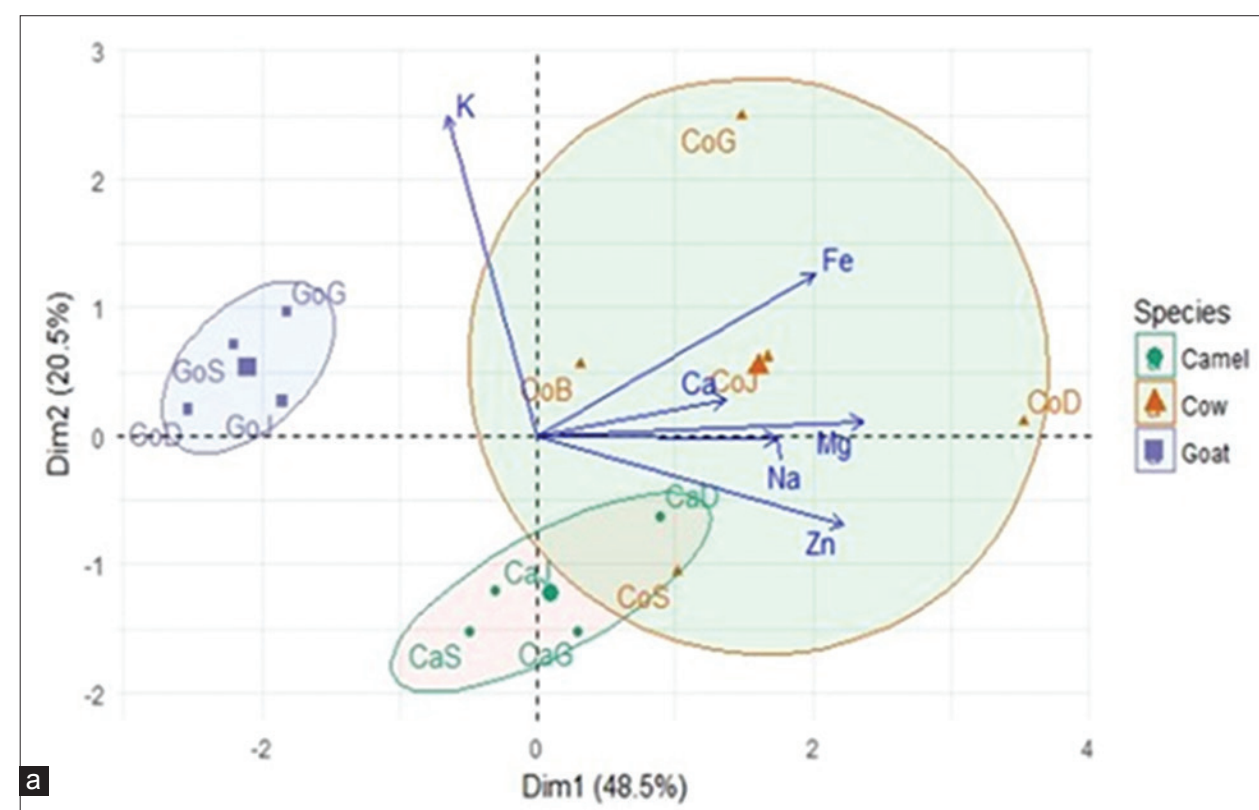

$7.5-$

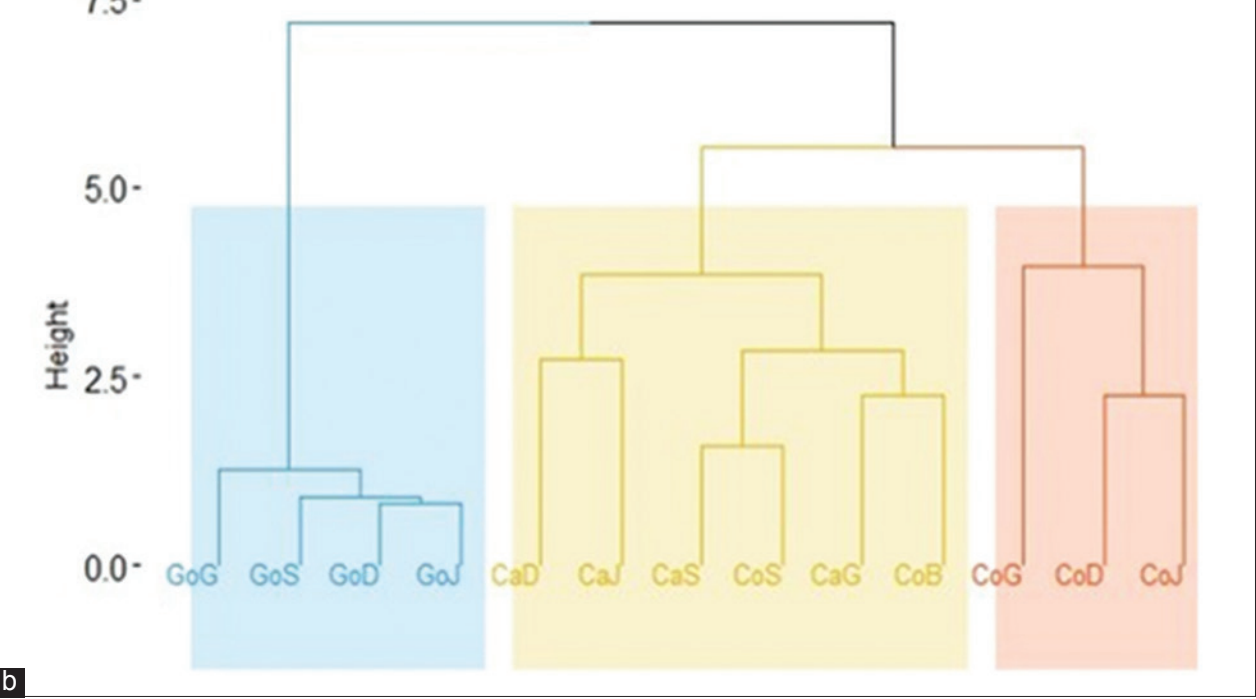

Figure-4: Principal component analysis distribution of fermented milk samples and ellipse of inertia different species on the factorial plane according to minerals concentration (a); ascending hierarchical clusters according to minerals concentration of fermented milk from different species (b).

$\mathrm{CaS}$ and $\mathrm{CaJ}$ were highly rich in $\mathrm{K}^{+}$. Dimension 2 reveals that $C a D$ was rich in $\mathrm{Zn}^{2+}$ and $\mathrm{Na}^{2+}$ and poor in $\mathrm{Fe}^{2+}, \mathrm{Ca}^{2+}$, and $\mathrm{Mg}^{2+}$, while $\mathrm{CoJ}, \mathrm{CoD}, \mathrm{GoD}, \mathrm{GoS}$, $G o J$, and $G o G$ were rich in $\mathrm{Fe}^{2+}, \mathrm{Ca}^{2+}$, and $\mathrm{Mg}^{2+}$ but poor in $\mathrm{Zn}^{2+}$ and $\mathrm{Na}^{2+}$. The AHC led to dendrogram which regroups three major clusters according to their minerals concentration (Figure-4b). The first cluster included the fermented milk samples from goat. The second cluster included the fermented milk samples from camel and cow (Bobo and Sebba). The third cluster contained the fermented cow's milk samples from the remaining localities (Djibo, Dori, and Gorom-Gorom).

\section{Discussion}

The quality and safety of fermented foods are decisive factors for producers and consumers. Microbial densities obtain during this study were higher than those reported by Bonfoh et al. [16],
Koussou et al. [17], Katinan et al. [18], and De et al. [19]. Total microbial flora in samples was high according to the criteria presented in Codex Standard for Fermented Milks which lays down the minimum sum of microorganisms $10^{7} \mathrm{CFU} / \mathrm{ml}$. The presence of high densities of microorganisms in these samples could be due to poor handling, inadequate heat treatment, and environmental conditions during the preparations and sale. As for the lactic acid bacteria, these results did not reflect poor quality of milk but more contributing to the improvement of its sanitary quality, because these microorganisms produce antibacterial substances and particular organic acids [20-24]. Yeasts are responsible for producing alcohol during the fermentation of milk. These results were similar to those reported by Savadogo et al. [25], Al-Tahiri [26], and Serhan and Mattar [27]. The assessment of hygienic quality detected the presence of thermotolerant coliforms and S. aureus in fermented milk. Several 







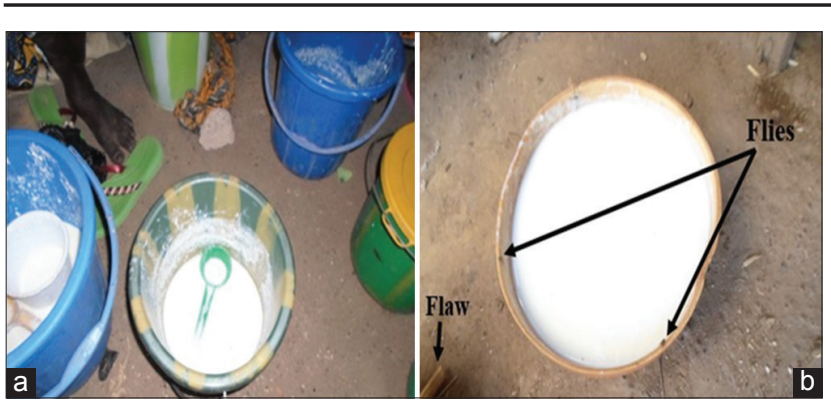

Figure-5: Milk sale in Dori (a) and Gorom-Gorom (b) market.

Semaan et al. [35], Cesbron-Lavau et al. [36], and Ayyash et al. [34] obtained similar values from traditional dairy products (milk and darfieh cheese), but other compositions are reported in review by Clark and Mora-Garcia [37]. Numerous studies reported that fermented milk and yogurt contain some nutritive components such as peptides and fatty acids, which are produced during fermentation. These components were known to modulate the immune system [38]. Yadav and Shukla [39] reported that fermented milk consumption could prevent the effect of ulcerative colitis. Camel milk differs from other milk (bovine) in its composition and protein content and structure, and, therefore, is expected to possess functional and bioactive properties different from bovine milk. Camel milk has an excellent reputation as nutritious food, with most of its therapeutic value related to its biological properties such as antioxidant activity [7].

Table-5 showed the average contents of minerals in various traditional fermented milks of Burkina Faso. The results revealed that camel fermented milk contains the highest concentration in $\mathrm{Na}^{2+}$ and $\mathrm{Ca}^{2+}$. High concentrations of $\mathrm{Ca}^{2+}, \mathrm{Mg}^{2+}$, and $\mathrm{Zn}^{2+}$ were reported by Navarro-Alarcón et al. [39] in commercial fermented milk of goat and cow, but Wang et al. [32] reported high concentrations to $\mathrm{K}^{+}(1724 \mathrm{mg} / \mathrm{Kg})$ and $\mathrm{Ca}^{2+}(1409 \mathrm{mg} / \mathrm{Kg})$ in fermented goat milk. . The concentration of $\mathrm{Ca}^{2+}, \mathrm{K}^{+}$, and $\mathrm{Mg}^{2+}$ in fermented milks could be due to the activity of the lactic bacteria during fermentation process $[40,41]$. The high rate of $\mathrm{Ca}^{2+}$ in milk of Djibo, Dori, and Gorom-Gorom is due to the high presence of limestone $\left(\mathrm{CaCO}_{3}\right)$ in the water of these cities: In general, the minerals concentration in fermented milk depends on the species, its individual characteristics, feeding method, rearing area, nature of metal of the material containing milk, degree of food contamination and drinking water, lactation stage, and health condition of female. The $\mathrm{Na}^{2+} / \mathrm{K}^{+}$ratio in the body helps to control blood pressure; fermented milk is a food source having impact in lowering blood pressure [42]. The $\mathrm{Na}^{2+} / \mathrm{K}^{+}$ratios (0.104-0.909) were obtained for the different fermented milk samples, and this low $\mathrm{Na}^{2+} / \mathrm{K}^{+}$ratio can help to control blood pressure. The $\mathrm{Ca}^{2+} / \mathrm{Mg}^{2+}$ ratio (3.392-6.464) for food was within the recommended value higher at 1.00 [42]. The fermented milk samples were a rich source of $\mathrm{Ca}^{2+}$ and $\mathrm{Mg}^{2+} \cdot \mathrm{K}^{+}$and $\mathrm{Ca}^{2+}$ are the most important elements for bone growth, development, metabolism, and health maintenance.

\section{Conclusion}

The traditional fermented milks and dairy products are important sources of functional nutrients. The fermented milks sold and consumed in Burkina Faso shown high variability in microbiological, physicochemical quality, and the minerals concentration. This study revealed that traditional fermented milk is a very important source of nutrients and functional food due to compounds in fats, proteins, carbohydrate, and low $\mathrm{Na}^{2+} / \mathrm{K}^{+}$ratio. The presence of lactic acid bacteria and yeast improves the organoleptic qualities of fermented milk and brings beneficial effects to consumers, while the presence of certain bacteria such as coliforms and $S$. aureus is a risk for the milk quality and the health of consumers. This work has important implications for the commercialization of fermented milk based on camel and goat milk. The sanitary practices followed by producers during handling, storage, and processing are generally poor. Based on the overall evaluation of the results, training to the local producers on good hygiene practices is necessary to improve sanitary quality of fermented milk sold in Burkina Faso.

\section{Authors' Contributions}

$\mathrm{HC}$ collected the samples and wrote the original draft of the manuscript. HC, JUM, and SMD analyzed the samples. NSS, AS, and FT organized the data, helped in writing, and review of the manuscript. $\mathrm{CZ}$, YT, and AlyS supervised the study, validated the results from analysis, and review of the manuscript. All authors have read and approved the final version.

\section{Acknowledgments}

This study was financially supported by local direction of scholarship (National Center for Information, School and Professional Orientation and Scholarships of Burkina Faso) and Laboratory of Applied Biochemistry and Immunology, Burkina Faso. The authors wish to express sincere gratitude to the staff of the National Laboratory of Public Health in Ouagadougou (Burkina Faso) for technical and personal assistance during the analysis of this project.

\section{Competing Interests}

The authors declare that they have no competing interests.

\section{Publisher's Note}

Veterinary World remains neutral with regard to jurisdictional claims in published map and institutional affiliation.

\section{References}

1. Rosa, D.D., Dias, M.M.S., Grzes-Kowiak, L.M., Reis, S.A., Conceição, L.L. and Peluzio, M.D.C. (2017) Milk kefir: Nutritional, microbiological and health benefits. Nutr. Res. Rev., 30(1): 82-96. 
2. Coulibaly, K.E., Coulibaly, K.J., Thierry, L., Akpa, E.E., Goualie, G.B., Niamke, S.L. and Dosso, M. (2017) Probiotic profiling of Leuconostoc species isolated from a traditional fermented cassava product. Afr. J. Microbiol. Res., 11(10): 408-413.

3. Deepika-Shree, K., Deshpande, H.W. and Bhate, M.A. (2017) Studies on exploration of psyllium husk as prebiotic for the preparation of traditional fermented food "Buttermilk". Int. J. Curr. Microbiol. Appl. Sci., 6(7): 3850-3863.

4. Yuvasen, A., Macit, E. and Dertli, E. (2018) Microbial species playing roles for the production of traditional Kasar cheese during pre-maturation period. LWT Food. Sci. Technol., 91(5): 406-413..

5. Coulibaly, K.J., Kouame-Elogne, C., Yeo, A., Koffi, C. and Dosso, M. (2015) Qualité microbiologique des produits laitiers industriels vendus à Abidjan de 2009 à 2012. Rev. Bio Afr., 14: 44-52.

6. Tankoano, A., Kabore, D., Savadogo, A., Soma, A., FanouFogny, N., Compaore-Sereme, D., Hounhouigan, D.J. and Sawadogo-Lingani, H. (2016) Evaluation of microbiological quality of raw milk, sour milk and artisanal yogurt from Ouagadougou, Burkina Faso. Afr. J. Microbiol. Res., 10(16): 535-541.

7. Al-Shamsi, K.A., Mudgil, P., Hassan, H.M. and Maqsood, S. (2018) Camel milk protein hydrolysates with improved techno-functional properties and enhanced antioxidant potential in in vitro and in food model systems. J. Dairy Sci., 101(1): 1-14.

8. Sharmaa, A., Viswanathb, B. and Parka, Y.S. (2018) Role of probiotics in the management of lung cancer and related diseases: An update. J. Funct. Foods., 40(1): 625-633.

9. Tankoano, A., Sawadogo-Lingani, H., Savadogo, A., Kabore, D. and Traore, Y. (2017a) Study of the process and microbiological quality of Gappal, a fermented food from Burkina Faso based on milk and millet dough. Int. J. Multidiscip. Curr. Res., 5(1): 104-110.

10. Ardalanian, F. and Fadaei, V. (2018) Production of probiotic doogh enriched with red ginseng extract. J. Agric. Sci. Technol., 20(2): 1-11.

11. Bozoudi, D., Kondyli, E., Claps, S., Hatzikamari, M., Michaelidou,A., Biliaderis, G.C. and Litopouloutzanetaki,E. (2018) Compositional characteristics and volatile organic compound of traditional PDO Feta cheese made in two different mountainous areas of Greece. Int. J. Dairy Technol., 71(3): 1-10.

12. Kerry, R.G., Patra, J.K., Gouda, S., Park, Y., Shin, H.S. and Das, G. (2018) Benefaction of probiotics for human health: A review. J. Food Drug Anal., 26(3): 927-939.

13. Sanders, P., Perrin-Guyomard, A. and Moulin, G. (2017) Evolution de l'utilisation des antibiotiques en production animale. Cah. Nutr. Diet., 52(6): 301-311.

14. AOAC. (2012) Animal feed. In: Latimer, G.W Jr., editor. Official Methods of Analysis of AOAC International. $19^{\text {th }}$ ed. Ch. 4. AOAC International, Gaithersburg, MD., USA. p18-19.

15. Egan, H., Kirk, R.S. and Sawyer, R. (1981) Pearson's Chemical Analyses of Food. $8^{\text {th }}$ ed. Churchill Livingstone, London-UK. p591.

16. Bonfoh, B., Fané, A., Traoré, N., Coulibaly, Z., Simbé, C.F., Alfaroukh, O.F., Nicolet, J., Farah, Z. and Zinsstag, J. (2002) Qualité microbiologique du lait et des produits laitiers vendus en saison chaude dans le district de Bamako au Mali. BIOTERRE, Rev. Inter. Sci., 8-9 (1-6): 242-250.

17. Koussou, M.O., Grimaud, P. and Mopate, L.Y. (2007) Evaluation de la qualité physico-chimique et hygiénique du lait de brousse et des produits laitiers locaux commercialisés dans les bars laitiers de N'Djamena au Tchad. Rev. Elev. Méd. Vét. Pays Trop., 60(1-4): 45-49.

18. Katinan, C.R., Sadat,A.W., Chatigre, K.O., Bohoussou, K.M. and Assidjo, N.E. (2012) Evaluation de la qualité chimique et microbiologique des laits caillés artisanaux produits et consommés dans la ville de Yamoussoukro, Côte d'Ivoire. J. Appl. Biosci., 55(7): 4020-4027.

19. De, N., Goodluck, T.M. and Bobai, M. (2014) Microbiological quality assessment of bottled yogurt of different brands sold in central market, Kaduna metropolis and Kaduna, Nigeria. Int. J. Curr. Microbiol. Appl. Sci., 3(2): 20-27.

20. Savadogo, A., Ouattara, C.A.T., Bassole, I.H.N. and Traore, S.A. (2006) Bacteriocins and lactic acid bacteria. Afr. J. Biotechnol., 5(9): 678-683.

21. Cissé, H., Savadogo, A., Taale, A., Tapsoba, F., Guira, F., Zongo, C. and Traore, Y. (2016) Influence des substrats carbonés et minéraux sur l'activité des BLIS produites par des souches de Bacillus isolées à partir d'aliments fermentés au Burkina Faso. J. Appl. Biosci., 106(10): 10236-10248.

22. Savadogo, A., Guira, F. and Tapsoba, F. (2016) Probiotic microorganisms involved in cassava fermentation for Gari and Attiéké production. J. Adv. Biotechnol., 6(2): 858-866.

23. Muandze, N.J.U., Guira, F., Cisse, H., Zongo, O., Zongo, C., Djbrine, A.O., Traore, Y. and Savadogo, A. (2017) Technological, biochemical and microbiological characterization of fermented cassava dough use to produce cassava stick, a Gabonese traditional food. Int. J. Multidiscip. Curr. Res., 5(4): 808-817.

24. Mortera, P., Zuljan, A.F., Magni, C., Bortolato, A.S. and Alarcon, H.S. (2018) Multivariate analysis of organic acids in fermented food from reversed-phase high-performance liquid chromatography data. Talanta., 178(2): 15-23.

25. Savadogo, A., Ouattara, C.A.T., Savadogo, P.W., Ouattara, A.S., Barro, N. and Traore, A.S. (2004b) Microorganisms involved in Fulani traditional fermented milk in Burkina Faso. Pak. J. Nutr., 3(2): 134-139.

26. Al-Tahiri, R. (2005) A comparison on microbial conditions between traditional dairy products sold in Karak and same products produced by modern dairies. Pak. J. Nutr., 4(5): 345-348.

27. Serhan, M. and Mattar, J. (2013) Characterization of four Lebanese artisanal goat milk cheeses: Darfiyeh, aricheh, shankleesh and serdale by physicochemical, microbiological and sensory analyses. J. Food Agric. Environ., 11(3-4): 97-101.

28. Yigrem, S. and Welearegay, H. (2015) Assessment of microbial quality and safety of a traditional fermented milk 'Irgo' collected from Hawassa city, South Ethiopia. J. Food. Process. Technol., 6(3): 431.

29. Cissé, H., Sawadogo, A., Kagambèga, B., Zongo, C., Traoré, Y. and Savadogo, A. (2018) Milk production and sanitary risk along the food chain in five cities in Burkina Faso. Urban Sci., 2(3): 57.

30. Savadogo, A., Ouattara, C.A.T., Ilboudo, A.J. and Traore, A.S. (2011) Mini review on contribution of HACCP system in raw and fermented milk quality in small dairy industries of Burkina Faso. N. Y. Sci. J., 4(1): 83-91.

31. De-Oliveira, M.N. (2014) Fermented milks and yogurt (in fermented milks). Encyc. Food Microbiol., 1(2 $2^{\text {nd }}$ ed): 908-922.

32. Wang, H., Wang, C., Wang, M. and Guo M. (2017) Chemical, physiochemical, and microstructural properties, and probiotic survivability of fermented goat milk using polymerized whey protein and starter culture Kefir Mild 01. J. Food Sci., 82(11): 2650-2658.

33. Abdelsalam, A.D., Abdelsalam, T., Balde, M., Safia, M.T.T., Musabyemariya, B., Alambedji, R., Babakar, K.S.S., Malang, S. and Bhen, S.T. (2013) Physicochemical characteristics of curdled milk and their correlation with the lactic flora in Chad. J. Food Stud., 2(2): 1-19.

34. Ayyash, M., Al-Dhaheri, S.A., Al-Mahadin, S., Kizhakkayil, J. and Abushelaibi, A. (2018) In vitro investigation of anticancer, antihypertensive, antidiabetic and antioxidant activities of camel milk fermented with camel milk probiotic: A comparative study with fermented bovine milk. J. Dairy Sci., 101(2): 1-12. 
35. Semaan, E.H., Dib, H., Ramia, A.R. and Chedid, M. (2011) Caractérisation chimique et qualité bactériologique de produits laitiers caprins traditionnels Libanais. Leban. Sci. J., 12(1): 21-29.

36. Cesbron-Lavau, E., Lubrano-Lavadera, A.S., Braesco, V. and Deschamps, E. (2017) Fromages blancs, petits-suisses et laits fermentés riches en protéines. Cah. Nutr. Diet., 52(1): 33-40.

37. Clark, S. and Mora-Garcia, B.M. (2017) A 100-year review: Advances in goat milk research. J. Dairy Sci., 100(12): 10026-10044.

38. Yadav, R. and Shukla, P. (2017) Probiotics for human health: Current progress and applications. In Recent advances in Applied Microbiology. Springer, Singapore, pp.133-147.

39. Navarro-Alarcón, M., Cabrera-Vique, C., Ruiz-López, D.M.,
Olalla, M., Artacho, R., Giménez, R., Quintana, V. and Bergillos, T. (2011) Levels of Se, $\mathrm{Zn}, \mathrm{Mg}$ and $\mathrm{Ca}$ in commercial goat and cow milk fermented products: Relationship with their chemical composition and probiotic starter culture. Food Chem., 129(3): 1126-1131.

40. Favier, J.C. (1987) Composition du yaourt. Cah. Nutr. Diet., 22(5): 373-379.

41. Ngounou, C.J., Ndjouenkeu, R., Mbofung, C.M.F. and Noubi, L. (2003) Mise en évidence de la biodisponibilité du calcium et du magnésium au cours de la fermentation du lait par des bactéries lactiques isolées du lait caillée de zébu. $J$. Food Eng., 57(3): 301-304.

42. Alinnor, I.J. and Oze, R. (2011) Chemical evaluation of the nutritive value of Pentaclethra macrophylla Benth (African oil bean) seeds. Pak. J. Nutr., 10(4): 355-359.

$* * * * * * * *$ 